\title{
Antimicrobial Activity of Photosynthetic Microorganisms Biomass Extract against Bacterial Isolates Causing Mastitis
}

\author{
José Noé da Silva Júnior ${ }^{1}$, Emanuelle Martins de Aguiar ${ }^{1}$, Rinaldo Aparecido Mota ${ }^{2}$, Raquel Pedrosa Bezerra ${ }^{1}$, \\ Ana Lúcia Figueiredo Porto ${ }^{1}$, Polyanna Nunes Herculano ${ }^{1}$ and Daniela de Araújo Viana Marques ${ }^{3 *}$
}

${ }^{1}$ Department of Morphology and Animal Physiology, Universidade Federal Rural de Pernambuco-UFRPE, Brazil

${ }^{2}$ Department of Veterinary Medicine, Universidade Federal Rural de Pernambuco, Brazil

${ }^{3}$ Serra Talhada Campus, University of Pernambuco, Brazil

Submission: January 30, 2019; Published: March 06, 2019

*Corresponding author: Daniela de Araújo Viana Marques, Serra Talhada Campus, University of Pernambuco, Avenida Afonso Magalhães, Centro, PE, 380, 56912-380 Serra Talhada, PE, Brazil

\begin{abstract}
Photosynthetic Microorganisms are organisms rich in bioactive compounds, which are used as food supplement and have various pharmacological properties, such as antibacterial potential. Mastitis is a pathology featured to inflammation of the udder, caused by fungi, bacteria or viruses. Mastitis treatment is by antibiotics intra-mammary infusion, and the indiscriminate use can cause resistance from the bacteria, hindering the therapy of this disease. The aim of this work was evaluated antimicrobial activity of Chlorella vulgaris, Arthrospira platensis and Dunaliella tertiolecta extracts against isolates causing goat (19 strains) and bovine (16 strains) mastitis, using broth microdilution method. The extracts were obtained using Sodium Acetate Buffer, 1 M, pH 5.5 (SAB), Water (W) and Chloroform-methanol (CM). The three microalgal extracts showed interesting antimicrobial properties, the lowest MIC value was of $25 \mu \mathrm{g} / \mathrm{mL}$ for C. vulgaris (CM extract) and Dunaliella tertiolecta (water extract) against Staphylococcus sp. of bovine mastitis and $25 \mu \mathrm{g} / \mathrm{mL}$ using SAB and water extracts from A. platensis, which mostly inhibited the growth of isolated Staphylococcus sp. of goat mastitis. These results could mean a breakthrough in the veterinary pharmaceutical industry and consequently a direct and effective applicability in veterinary medicine, reducing damage caused by mastitis in bovine and goat herds.
\end{abstract}

Keywords: Photosynthetic Microorganisms; Mastitis; Minimum inhibitory concentration (MIC); Antimicrobial activity

Abbreviations: MIC: Minimum Inhibitory Concentration; CM: Chloroform-Methanol; W: Water; VISA: Vancomycin Intermediate Resistant Staphylococcus aureus;

\section{Introduction}

For decades, it is increasing the use of microalgae in various sectors of Biotechnology, due to the amount and also the complexity of bioactive compounds that these organisms can synthesize [1]. Chlorella vulgaris, Dunaliella tertiolecta and Arthrospira platensis were one of these photosynthetic microorganisms classes, considered structurally simple, being abundant in nature and has high capacity for cell multiplication. Requiring basically $\mathrm{CO}_{2}$, light and some minerals, they are commercially produced worldwide. Among the main chemical compounds produced by these photosynthetic microorganisms, we can highlight vitamins, polysaccharides, immunostimulatory and antibacterial compounds, proteins, antioxidants and minerals [2]. For this reason, photosynthetic microorganisms extract is being searched and used in various applications to combat animal or human infections caused by microorganisms. Mastitis is a pathology featured to inflammation of the udder, caused by a variety of microorganisms, such as fungi, bacteria and viruses. Among the mastitis-causing bacteria, there is Staphylococcus aureus, which is dramatically affecting the bovine and goat health in herds that comprise Brazil Northeast region, producing a fully thermostable toxin harmful to human health. In addition, mastitis is a highly prevalent disease in dairy cattle and the most costly for the dairy industry worldwide, cause considerable economic losses due in the milk production and quality, increased cost of treatment and veterinary services, and loss of animals [3,4]. The use of antibiotics in cattle, and even the use of recommended products from goats sheep pose a high risk because the safety and efficacy of these drugs in each species are still, for the most part 
unknown. Therefore, it is necessary to search for new bioactive for veterinary use.

The future of antibiotics is still uncertain because of microbial resistance that is increasing. Antimicrobial drugs normally used clinically have downsides as toxicity, lack of efficacy, high cost and resistance of some bacteria. In this way, there is a grave need to obtained alternative biodegradable agents, which should be free from collateral effects. Natural compounds have this characteristic and so more environmentally acceptable. In the pharmaceutical sector, few drugs and other biologically active compounds from photosynthetic microorganisms, as yet, have commercial applications with effective for use, specifically, in small ruminants, mainly in goats. So, this search prompted the exploration of natural algal products [1]. Different commercialization prices of macroalgae products have been reported a decrease in the marketing prices (except for omega-3). This can be explained by the fact that more companies are focusing in the production and commercialization of compounds from microalgae. Nevertheless, prices are still high due to the process expenses associated to the extraction and purification of intracellular metabolites [5]. Five decades ago, in Japan in 1960s, has begun the commercial cultivation and application of microalgae. Around 7.5 million tonnes is the annual production of microalge and Chlorella genus was the first targeted organism. The global market value of micro-algae is estimated to be around US $\$ 6.5$ billion, out of which about US $\$ 2.5$ billion is generated by the health food sector, US $\$ 1.5$ billion by the production of DHA and US\$700 million by aquaculture [6].

The objective of this work is assess antimicrobial activity of the Chlorella vulgaris and Dunaliella tertiolecta microalgae extracts, and cyanobacteria extract from Arthrospira platensis, obtained through tree different solvents: water, sodium acetate buffer and chloroform-methanol, against isolates causing bacteria bovine and goat mastitis, aiming therefore their application in the pharmaceutical industry, contributing to the advancement of Veterinary Medicine.

\section{Materials and Methods}

\section{Collection of Microalgae and Bacteria}

Chlorella vulgaris [7], Arthrospira platensis [7] and Dunaliella tertiolecta [7] were obtained from collection culture of Texas University. The pathogenic microorganisms was Staphylococcus $s p$. isolates from bovine (7AE, 17AE, $18 \mathrm{AE}, 12 \mathrm{AD}, 6 \mathrm{PD}, 8 \mathrm{PD}, 13 \mathrm{PD}$, $15 \mathrm{PD}, 19 \mathrm{PD}, 22 \mathrm{PD}, 5 \mathrm{PE}, 8 \mathrm{PE}, 15 \mathrm{PE}, 18 \mathrm{PE}, 19 \mathrm{PE}$ and $20 \mathrm{PE})$ and goat $(1,2,3,4,9,24,29.2,30.2,32,40,43.2,48,50,292,310,350$, $601,51 \mathrm{E}, 11 \mathrm{D})$ mastitis, obtained of bacterial collections in Bacterioses Laboratory, Medicina Veterinary Department of UFRPE, Recife, Pernambuco, Brazil. Bacterial strains stock cultures were kept on Trypticasein Soy Broth (TSB) at $6{ }^{\circ} \mathrm{C}$.

\section{Microalgae growth}

C. vulgaris was maintained and growth on Bold's Basal Medium [8], Arthrospira platensis in standard medium described by Schlösser [9] and Dunaliella tertiolecta in Guillard F/2 medium
[10] constitute of sea water supplemented with salts and vitamins; all at temperature $25{ }^{\circ} \mathrm{C}$ and under continuous light intensity of $72 \mu \mathrm{mol}$ photons $\mathrm{m}-2 \mathrm{~s}-1$. At the late exponential growth phase, the microalgae harvested by centrifugation at $3500 \mathrm{xg}$ for $10 \mathrm{~min}$ and the cell used to antimicrobial extraction by different solvents.

\section{Extraction process using different solvents}

Extracts from microalgae and cyanobacteria biomass were prepared using sodium acetate buffer, 1M, pH 5.5 (SAB) [11], distilled water (W) and 2:1 chloroform-methanol (CM) as solvents. One hundred grams of cell dried with $1 \mathrm{ml}$ of solvent were mixed and sonicated at 20 pulses in ice baths with intervals of 1 minute between each pulse. After extraction, the extracts were centrifuged at $4{ }^{\circ} \mathrm{C}$ at $2500 \mathrm{rpm}$ for 5 minutes and supernatant used to antimicrobial activity. To extract using CM, the supernatant were evaporated at room temperature until constant weight and ressuspended with dimethyl sulfoxide (DMSO) to 6\%. The antimicrobial activity of the extracts obtained with different solvents was tested against bacterial species.

\section{Antimicrobial assay}

The minimal inhibitory concentration (MIC) was determined for all algal extracts (W, SAB and CM) using the broth microdilution method recommended by CLSI [12]. Briefly, $50 \mu$ l of 6 different concentration of each microalgae extract 100 to $1 \mathrm{mg} / \mathrm{mL}$ were pipetted in 96-well microtiter plates with fresh bacterial cultures suspended in Muller Hinton broth completing a $100 \mu \mathrm{L}$ of final volume. The final bacterial cells concentration was adjusted to $107 \mathrm{CFU} / \mathrm{ml}$. Microbial growth was determined by absorbance at $600 \mathrm{~nm}$ using the Microplate manager 4.0 Bio-Rad Laboratories. The extract tested in this study was screened three times against each organism. MIC was determined as the lowest extract concentration that prevents visible bacterial growth after $24 \mathrm{~h}$ of incubation at $37^{\circ}$ C. Results for MIC of Chlorella vulgaris extract using W and $\mathrm{CM}$ solvents were expressed in $\mu \mathrm{g} / \mathrm{mL}$ and for $\mathrm{SAB}$, in $\mathrm{mg}$ / $\mathrm{mL}$. Appropriate controls of medium with microorganisms or each extract were included. The assay was performed in triplicates and the final results were presented as the arithmetic average.

\section{Results}

\section{Antimicrobial activity of Chlorella vulgaris extracts against bacteria isolated from bovine and goat mastitis}

Antimicrobial activity of C. vulgaris extracts prepared by using chloroform:methanol solvent (8 isolates), water (10 isolates) and sodium acetate buffer (13 isolates) against bovine mastitis was recorded in Table 1. Data clearly show the high potency of C. vulgaris extracts to inhibit the Staphylococcus sp. growth. C. vulgaris extracts obtained by aqueous solvents, water and sodium acetate buffer (W and SAB), and chloroform-methanol (CM) were able to inhibit all bovine mastitis isolates tested. However, aqueous solvents extraction was more efficient, with MIC at 100 to $50 \mu \mathrm{g} / \mathrm{mL}$ (Table 1 ), highlighting also that all extracts inhibited the isolates with $\mathrm{IC}_{50} \%$ at low concentrations of $3 \mathrm{mg} / \mathrm{mL}$. 
Table 1: Minimum Inhibitory Concentration (MIC) and $\mathrm{IC}_{50}(\%)$ of Chlorella vulgaris extract obtained by 3 different solvents against Staphylococcus $\mathrm{sp}$. isolates causing bovine mastitis.

\begin{tabular}{|c|c|c|c|c|c|c|}
\hline \multirow[t]{2}{*}{ Extract concentration } & \multicolumn{2}{|c|}{$\begin{array}{c}\mathbf{W} \\
(\mu \mathrm{g} / \mathrm{mL})\end{array}$} & \multicolumn{2}{|c|}{$\begin{array}{c}\text { SAB } \\
(\mathrm{mg} / \mathrm{mL})\end{array}$} & \multicolumn{2}{|c|}{$\begin{array}{c}\text { CM } \\
(\mu \mathrm{g} / \mathrm{mL})\end{array}$} \\
\hline & MIC (\%) & $\mathrm{IC}_{50}(\%)$ & MIC (\%) & $\mathrm{IC}_{50}(\%)$ & MIC (\%) & $\mathrm{IC}_{50}(\%)$ \\
\hline 100 & $3(30 \%)$ & $1(10 \%)$ & $5(38.5 \%)$ & $1(7.7 \%)$ & $1(12.5 \%)$ & $*$ \\
\hline 50 & $1(10 \%)$ & $2(20 \%)$ & $2(15.4 \%)$ & $*$ & $*$ & $*$ \\
\hline 25 & $*$ & * & $*$ & $*$ & $1(12.5 \%)$ & * \\
\hline 12 & $*$ & $*$ & $*$ & $*$ & $*$ & $*$ \\
\hline 6 & * & * & $*$ & $*$ & $*$ & * \\
\hline 3 & * & $3(30 \%)$ & $*$ & $5(38.5 \%)$ & $*$ & $6(75 \%)$ \\
\hline 1 & $*$ & $*$ & $*$ & $*$ & $*$ & $*$ \\
\hline
\end{tabular}

$\left({ }^{*}\right)$ - No MIC and no IC ${ }_{50}$ were observed.

The results of the antimicrobial activity against Staphylococcus sp. from goat mastitis (W: 4; SAB: 8; CM: 4 isolates) have been presented in Table 2. Aqueous and chloroform:methanol extracts of $C$. vulgaris biomass using water not showed MIC in any concen-

tration. In this mastitis type, it was observed MIC only through $\mathrm{SAB}$ extraction, at $100 \mathrm{mg} / \mathrm{mL}$. Half-maximal inhibitory concentration ( $\mathrm{IC}_{50} \%$ ) values were observed from 25 and $3 \mathrm{mg} / \mathrm{mL}$ using the same extraction method.

Table 2: Minimum Inhibitory Concentration (MIC) and $\mathrm{IC}_{50}(\%)$ of Chlorella vulgaris extract obtained by 3 different solvents against Staphylococcus $\mathrm{sp}$. isolates causing goat mastitis.

\begin{tabular}{|c|c|c|c|c|c|c|}
\hline $\begin{array}{c}\text { Extract concen- } \\
\text { tration }\end{array}$ & \multicolumn{2}{|c|}{$\begin{array}{c}\text { SAB } \\
(\mu \mathrm{g} / \mathrm{mL})\end{array}$} & \multicolumn{2}{c|}{$\begin{array}{c}\text { CM } \\
(\mu \mathrm{g} / \mathrm{mL})\end{array}$} \\
\hline & MIC (\%) & $\mathbf{I C}_{50}(\%)$ & MIC (\%) & IC $_{50}(\%)$ & MIC (\%) & IC $_{50}(\%)$ \\
\hline 100 & $*$ & $2(50 \%)$ & $2(25 \%)$ & $*$ & $*$ & $*$ \\
\hline 50 & $*$ & $*$ & $*$ & $*$ & $*$ & $*$ \\
\hline 25 & $*$ & $*$ & $*$ & $*$ & $*$ & $*$ \\
\hline 12 & $*$ & $1(25 \%)$ & $*$ & $*$ & $*$ & $*$ \\
\hline 6 & $*$ & $*$ & $*$ & $4(50 \%)$ & $*$ & $*$ \\
\hline 3 & $*$ & $*$ & $*$ & $*$ & $*$ \\
\hline 1 & $*$ & $*$ & $*$ & $*$ & $*$ \\
\hline
\end{tabular}

$\left(^{*}\right)$ - No MIC and no IC ${ }_{50}$ were observed.

\section{Antimicrobial activity of Dunaliella tertiolecta extracts against bacteria isolated from bovine and goat mastitis}

Table 3: Minimum Inhibitory Concentration (MIC) and $\mathrm{IC}_{50}(\%)$ of Dunaliella tertiolecta extract obtained by 3 different solvents against Staphylococcus $s p$. isolates causing bovine mastitis.

\begin{tabular}{|c|c|c|c|c|c|c|}
\hline \multirow[t]{2}{*}{$\begin{array}{l}\text { Extract concen- } \\
\text { tration }\end{array}$} & \multicolumn{2}{|c|}{$\begin{array}{c}\mathbf{W} \\
(\mu \mathrm{g} / \mathbf{m L})\end{array}$} & \multicolumn{2}{|c|}{$\begin{array}{c}\text { SAB } \\
(\mathrm{mg} / \mathrm{mL})\end{array}$} & \multicolumn{2}{|c|}{$\begin{array}{c}\text { CM } \\
(\mu \mathrm{g} / \mathrm{mL})\end{array}$} \\
\hline & MIC (\%) & $\mathrm{IC}_{50}(\%)$ & MIC (\%) & $\mathrm{IC}_{50}(\%)$ & MIC (\%) & $\mathrm{IC}_{50}(\%)$ \\
\hline 100 & $*$ & $*$ & $*$ & $*$ & * & $*$ \\
\hline 50 & $*$ & $*$ & * & * & $*$ & $*$ \\
\hline 25 & $2(33.3 \%)$ & $3(50 \%)$ & $*$ & * & * & * \\
\hline 12 & * & $1(16.7 \%)$ & * & $*$ & * & * \\
\hline 6 & $*$ & $*$ & $*$ & $1(14.3 \%)$ & $*$ & $*$ \\
\hline 3 & $*$ & * & $*$ & $6(85.7 \%)$ & $*$ & $3(100 \%)$ \\
\hline 1 & * & * & * & $*$ & * & $*$ \\
\hline
\end{tabular}

$\left(^{*}\right)$ - No MIC and no IC ${ }_{50}$ were observed. 
Table 4: Minimum Inhibitory Concentration (MIC) and IC50 (\%) of Dunaliella tertiolecta extract obtained by 3 different solvents against Staphylococcus sp. isolates causing goat mastitis.

\begin{tabular}{|c|c|c|c|c|c|c|}
\hline \multirow[t]{2}{*}{$\begin{array}{c}\text { Extract concen- } \\
\text { tration }\end{array}$} & \multicolumn{2}{|c|}{$\begin{array}{c}\mathbf{W} \\
(\mu \mathrm{g} / \mathbf{m L})\end{array}$} & \multicolumn{2}{|c|}{$\begin{array}{c}\mathrm{SAB} \\
(\mathrm{mg} / \mathrm{mL})\end{array}$} & \multicolumn{2}{|c|}{$\begin{array}{c}\text { CM } \\
(\mu \mathrm{g} / \mathbf{m L})\end{array}$} \\
\hline & MIC (\%) & $\mathrm{IC}_{50}(\%)$ & MIC (\%) & $\mathrm{IC}_{50}(\%)$ & MIC (\%) & $\mathrm{IC}_{50}(\%)$ \\
\hline 100 & $*$ & * & $4(80 \%)$ & * & $*$ & * \\
\hline 50 & $13(100 \%)$ & * & $*$ & * & $*$ & $*$ \\
\hline 25 & $*$ & * & * & * & $*$ & * \\
\hline 12 & * & * & * & * & $*$ & * \\
\hline 6 & * & * & * & * & $*$ & * \\
\hline 3 & * & * & * & $*$ & $*$ & $1(100 \%)$ \\
\hline 1 & $*$ & * & $*$ & * & $*$ & $*$ \\
\hline
\end{tabular}

$\left(^{*}\right)$ - No MIC and no IC 50 were observed.

Inhibition values of the tested bovine mastitis isolates (W:6; SAB: 7; CM: 3 isolates) using extracts of Dunaliella tertiolecta were presented in Table 3. MIC using water extraction solvent was observed only for 2 isolates. The obtained results showed that SAB extracts used at $\mathrm{IC}_{50} \%$ values of 6 to $3 \mathrm{mg} / \mathrm{mL}$ were able to su-

ppress bacteria survival. Table 4 shows the results of Dunaliella tertiolecta extracts inhibiting goat mastitis isolates (W: 13; SAB: 5; CM: 1 isolates). Samples obtained from water solvent extraction showed MIC values at $50 \mu \mathrm{g} / \mathrm{mL}$ against all isolates studied.

\section{Antimicrobial activity of Arthrospira platensis extracts against bacteria isolated from bovine and goat mastitis}

Table 5: Minimum Inhibitory Concentration (MIC) and IC50 (\%) of Arthrospira platensis extract obtained by 3 different solvents against Staphylococcus $\mathrm{sp}$. isolates causing bovine mastitis.

\begin{tabular}{|c|c|c|c|c|c|c|}
\hline $\begin{array}{c}\text { Extract concen- } \\
\text { tration }\end{array}$ & \multicolumn{2}{|c|}{$\begin{array}{c}\text { S } \\
(\mu \mathrm{g} / \mathrm{mL})\end{array}$} & \multicolumn{2}{c|}{$\begin{array}{c}\text { CM } \\
(\mu \mathrm{mg} / \mathrm{mL})\end{array}$} \\
\hline & MIC (\%) & IC $_{50}(\%)$ & MIC (\%) & IC $_{50}(\%)$ & MIC (\%) & IC $_{50}(\%)$ \\
\hline 100 & $1(7.1 \%)$ & $5(35.7 \%)$ & $*$ & $*$ & $*$ & $*$ \\
\hline 50 & $*$ & $3(21.4 \%)$ & $*$ & $8(57.1 \%)$ & $*$ & $*$ \\
\hline 25 & $*$ & $4(28.6 \%)$ & $*$ & $4(28.6 \%)$ & $*$ & $2(50 \%)$ \\
\hline 12 & $*$ & $*$ & $*$ & $2(14.3 \%)$ & $*$ & $*$ \\
\hline 6 & $*$ & $*$ & $*$ & $*$ & $*$ & $*$ \\
\hline 3 & $*$ & $*$ & $*$ & $*$ & $*$ & $*$ \\
\hline 1 & $*$ & $*$ & $*$ & $*$ & $*$ & $*$ \\
\hline
\end{tabular}

$\left.{ }^{*}\right)$ - No MIC and no IC ${ }_{50}$ were observed.

Table 6: Minimum Inhibitory Concentration (MIC) and IC50 (\%) of Arthrospira platensis extract obtained by 3 different solvents against Staphylococcus $\mathrm{sp}$. isolates causing goat mastitis.

\begin{tabular}{|c|c|c|c|c|c|c|}
\hline \multirow[t]{2}{*}{$\begin{array}{l}\text { Extract concen- } \\
\text { tration }\end{array}$} & \multicolumn{2}{|c|}{$\begin{array}{c}W \\
(\mu \mathrm{g} / \mathrm{mL})\end{array}$} & \multicolumn{2}{|c|}{$\begin{array}{c}\text { SAB } \\
(\mathrm{mg} / \mathrm{mL})\end{array}$} & \multicolumn{2}{|c|}{$\begin{array}{c}\text { CM } \\
(\mu \mathrm{g} / \mathrm{mL})\end{array}$} \\
\hline & MIC (\%) & $\mathrm{IC}_{50}(\%)$ & MIC (\%) & $\mathrm{IC}_{50}(\%)$ & MIC (\%) & $\mathrm{IC}_{50}(\%)$ \\
\hline 100 & $4(25 \%)$ & $1(6.3 \%)$ & $3(18.8 \%)$ & $1(6.3 \%)$ & $*$ & $2(66.7 \%)$ \\
\hline 50 & $*$ & $1(6.3 \%)$ & $2(12.3 \%)$ & $3(18.8 \%)$ & $*$ & $1(33.3 \%)$ \\
\hline 25 & $4(25 \%)$ & 3 (18.8\%) & $3(18.8 \%)$ & $1(6.3 \%)$ & * & $*$ \\
\hline 12 & $*$ & $1(6.3 \%)$ & $*$ & $2(12.3 \%)$ & $*$ & * \\
\hline 6 & $*$ & $2(12.3 \%)$ & $*$ & $*$ & $*$ & $*$ \\
\hline 3 & $*$ & $*$ & $*$ & $1(6.3 \%)$ & $*$ & $*$ \\
\hline 1 & $*$ & $*$ & $*$ & $*$ & $*$ & $*$ \\
\hline
\end{tabular}

$\left({ }^{*}\right)$ - No MIC and no $\mathrm{IC}_{50}$ were observed.

The present study also examines minimum inhibitory concentration and $\mathrm{IC}_{50} \%$ of Arthrospira platensis extracts at W and SAB (14 bovine mastitis isolates tested) and CM (4 isolates). Table 5 exhibits that MIC only at high concentration of $\mathrm{W}$ extracts was more efficient. It can be highlighting which CM extract inhibited all isolates at $\mathrm{IC}_{50} \%$. Against Staphylococcus sp. isolates from goat mastitis (W:16; SAB: 16; CM: 3 isolates), the results were different (Table 6). 


\section{Discussion}

Its known that there is a growing resistance of some bacterial strains arising from the widespread and essentially unrestricted use of antibiotics in cattle handling [13], which affects quality and milk production, and consequently causes economic loss in the dairy industry [14]. Thus, in general, antibiotics used for mastitis are penicillin (42\%), ampicillin (26\%) and tetracyclines (18\%), and as in Brazil, S. aureus is considered the main causal agent of mastitis, the resistance observed for those groups of drugs cited is around $80 \%$ [15]. Moreover, the diversity antimicrobial activity of natural products against Staphylococcus $s p$. is associated with the origin of the extracts and also with physical-chemical characteristics as temperature, $\mathrm{pH}$, solubility, polarity, among others [16].

In this way, studies of Anabaena virabilis and Anabaena sp. blue green microalgae aqueous extracts were not effective against in vitro generated vancomycin intermediate resistant Staphylococcus aureus (VISA) strains, while all the organic (hexane, chloroform and methanolic) extracts showed activity against VISA strains with MIC of 32-64 $\mu \mathrm{g} / \mathrm{ml}$ [17]. Similar results could be observed in our work using CM extracts of Chlorella vulgaris (100 and $25 \mu \mathrm{g} / \mathrm{ml})$ against Staphylococcus sp. strains from bovine mastitis. In addition, aqueous and ethanolic extracts of Portulaca oleracea L against Staphylococcus aureus of cow mastitis was evaluated by Shumin [18]. The results showed that ethanolic extracts (MIC $=250 \mathrm{mg} / \mathrm{mL}$ ) had higher antibacterial activities than aqueous extracts (MIC of $500 \mathrm{mg} / \mathrm{mL}$ ); it is worth noting that these values were much higher than obtained in the present study for all microalgae.

Biological activity as antimicrobial depends on both algal species and the solvents used for their extraction [19]. Rajasulochana [20] reached the conclusion that chloroform: methanol is one of the main solutions for extracting the active antibacterial substances from the brown algae species. For $C$. vulgaris microalgae, test against Gram positive and Gram negative bacteria is generally assayed using aqueous and solvent extracts such as acetone, ether and chloroform, methanol [21]. Brown algal organic and aqueous extracts were tested for their antibacterial activity against multidrug resistant clinical three different isolates of $S$. aureus. Ethanol and diethyl ether extracts were more efficient with MIC value around $8 \mu \mathrm{g} / \mathrm{mL}$. Additionally, phytochemical analysis of seaweeds showed the presence of indoles, terpenes, acetogenins, phenols, fatty acids and volatile halogenated hydrocarbons in the selected species [22]. Meanwhile, organic extracts from all microalgae tested in this work also demonstrated $\mathrm{IC}_{50} \%$ values between $3-12 \mu \mathrm{g} /$ mL.

$\mathrm{CM}$ and $\mathrm{SAB}$ were the most effective solvents in antimicrobial tests of $C$. vulgaris extract, against bovine mastitis isolates. Ghosh [23] affirm that buffers and organic solvents are significantly effective in antimicrobial compounds extraction, and buffers also sodium acetate and sodium phosphate can be used to antimicrobial phicobiliproteins extraction. Similar to results obtained in this study, Medina-Jaritz [24], verified that methanolic extracts obtai- ned by Arthrospira maxima showed higher antimicrobial activity against Gram-positive and Gram-negative bacteria, compared with aqueous extract. According our results, mainly using Chlorella vulgaris extracts, goat mastitis isolates showed more resistance when compared with bovine mastitis bacteria. The mechanisms involved in this resistance are not completely elucidated, but it's know that the indiscriminate use of antibiotics is responsible for antibacterial resistance of Staphylococcus species in small ruminants, specifically in Northeast Region of Brazil [25]. Furthermore, variation in the susceptibility of tested pathogens against same extract could probably due to the phylogeny of the bacterial species [26] This explains the greater effectiveness of extracts from $D$. tertiolecta (MIC at $50 \mu \mathrm{g} / \mathrm{mL}$ of water solvent extracts) and Arthrospira platensis against bacteria from goat mastitis, different from the one observed for $C$. vulgaris extracts.

In this way, El-Sheekh [27] studied antimicrobial activity of the ethanol extracts from S.platensis against the most resistant isolate inside the Gram-positive bacteria group-Staphylococcus aureus. The Minimum inhibitory concentration (MIC) of the material extracted and purified from S.platensis was $65 \mu \mathrm{g} / \mathrm{mL}$. In this research aqueous extracts from A.platensis were more active, with emphasis on water solvent, presented MIC around $25 \mu \mathrm{g} / \mathrm{mL}$. In addition, Laport [28] studied antibacterial activity of extracts from the sponge species Cinachyrella sp., Haliclona sp. and Petromica citrina. In the total of 49 CNS strains isolated from bovine mastitis, $61 \%$ were inhibited, including strains resistant to conventional antibiotics. Extracts from P. citrina showed the largest spectrum of inhibitory activity. The aqueous extract (water solvent) inhibited $51 \%$ of the CNS strains and presented a bactericidal effect over susceptible and multiresistant-bacteria at a minimal inhibitory concentration of $1.024 \mu \mathrm{g} / \mathrm{mL}$. The action of this extract on $S$. aureus ATCC 29213 and S. epidermidis ATCC 14990 was also inhibitory at a MIC of $512 \mu \mathrm{g} / \mathrm{mL}$. According Marinho [29], the effect of the active compounds extracted from P. citrina affects protein biosynthesis of Staphylococcus spp.

Meantime, in general, extracts obtained with water solvent are not as effective, in antimicrobial tests, when compared with organic solvents and buffers. Compounds extraction responsible for antimicrobial activity was related with the polarity of the solvent employed, and organic solvents with low polarity can be more efficient in antimicrobial compounds extraction from microgalgae [30], although several authors related that others organic solvents obtained by microalgae and cyanobacteria with high polarity, also methanol, showed antimicrobial activity due to the presence of $\gamma$-linolenic acid [31]. Also, in addition to the fatty acids, it has been suggested that antimicrobial activity of C. vulgaris, Arthrospira platensis and Dunaliella genus could be attributed to its proteins, vitamins, carotenoids and phenolic compounds [32]. D. tertiolecta extracts are rich in polyphenols, and considering that the antimicrobial activity of these compounds is already known [33], extraction using organic solvent and buffers are more recommended, as can be seen in our results. Some authors observed that Dunaliella salina produced antibiotic substances, mainly active on 
E. coli, P. aeruginosa, S. aureus, Candida albicans, and Aspergillus niger [21,34], and the butanol extract was shown to be active on $P$. aeruginosa and Klebsiella pneumoniae [35].

In relation to proteins, some pigments as phycocyanin and phycoerithrin produced in majority for cyanobacteria and red algae are water-soluble and can be easily extracted as a protein-pigment complex [36]. General procedure includes a first extraction in buffer solutions (phosphate buffer) with sonication or ultrasound as cell disruption pretreatment. However, pretreatment times should not be long in order to avoid proteins destabilization [5]. Newly, phycobiliproteins have been shown potent medical and pharmacological properties [37] such as anti-inflammatory, antioxidant, antitumor activities, hepatoprotective and neuroprotective effects. Nonetheless, there is lack of reports of antimicrobial activity in the literature. The first study of phycobiliproteins as antimicrobial compounds was observed by Sarada [38] that obtained a purified phycocyanin (extracted in $10 \mathrm{mM}$ potassium phosphate buffer pH 7.0) from Spirulina platensis as a potent agent against Escherichia coli, Klebsiella pneumoniae, Pseudomonas aeruginosa and S. aureus. Meanwhile, phycocyanins of Porphyridium aerugineum and Porphyridium cruentum, two red microalgae, extracted using Tris-base with EDTA buffer, pH 6,8, were active against $S$. aureus and Streptococcus pyogenes [39]. It's known that with the impact of infectious diseases on global health and the continued emergence of antibiotic resistance, economic and environmental studies regarding to obtainment high-value compounds from microalgae are needed.

On the basis of what reported above and considering the antibiotic-resistance of bacterial strains, the increased occurrence of nosocomial infections, and the consequent increasing request of new antimicrobials for the treatment of infectious diseases, microalgae consist - depending on the type and the family to which it belongs, and the conditions in which it has grown - in a rich source of bioactive substances, with a wide range of applications and may be in the coming future a valuable therapeutic support opening new perspectives for the utilization of new and still unexploited sources of drugs. This study confirms significant potential of biotechnological extracts obtained from microalgae Chlorella vulgaris and Dunaliella tertiolecta and the cyanobacteria Arthrospira platensis with satisfactory degree of the isolates growth inhibition contributing thus to the advancement of Veterinary Medicine and also improving the quality of human life, as well decrease the infections in the herd and become it more healthy and free of pathogenic microorganisms.

\section{Conflicts of Interest}

The authors have declared that there are no conflicts of interest.

\section{Acknowledgement}

The authors acknowledge the financial support of the Foundation for Research Support of the State of Pernambuco (FACEPE) - Brazil.

\section{References}

1. Pradhan J, Das BK, Sahu S, Marhual NP, Swain AK, et al. (2012) Traditional antibacterial activity of fresh water microalga Spirulina platensis to aquatic pathogens. Aquaculture Research 43(9): 12871295.

2. Mohan N, Hanumantha Rao P, Ranjith R, Sivasankaran S, Sivasubramanian V (2009) Studies on mass cultivation of Chlorella vulgaris and effective harvesting of biomass by low-cost methods. Journal of Algal Biomass Utilization 1(1): 29-39.

3. Hogeveen H, Huijps K, Lam TJ (2011) Economic aspects of mastitis: New developments. The New Zealand Veterinary Journal 59(1): 16-23.

4. Ismail ZB (2017) Mastitis vaccines in dairy cows: Recent developments and recommendations of application. Veterinary World 10(9): 10571062 .

5. Cuellar-Bermudez SP, Aguilar-Hernandez I, Cardenas-Chavez DL, Ornelas-Soto N, Romero-Ogawa MA, et al. (2015) Extraction and purification of high-value metabolites from microalgae: essential lipids, astaxanthin and phycobiliproteins. Microbial Biotechnology 8(2): 190-209.

6. Mobin S, Firoz A (2017) Some promising microalgal species for commercial applications: A review. Energy Procedia 110: 510-517.

7. http://www.sbs.utexas.edu/

8. Bischoff H W, Bold HC (1963) Phycological Studies. IV. Some Algae from Enchanted Rock and Related Algae Species. University of Texas Publications 6318: 1-95.

9. Schlösser UG (1982) Sammlung von Algenkulturen. Ber Dtsch Bot Ges 95: 181-276.

10. Guillard RRL, Ryther JH (1962) Studies of marine planktonic diatoms: I. Cyclotella nana Hustedt and Detonula confervacea (Cleve) Gran. Journal of Microbiology 8(2): 229-239.

11. Bermejo RR, Talavera EM, Alvarez-Pez JM (2001) Chromatographic purification and characterization of b-phycoerythrin from Porphyridium cruentum. Semipreparative HPLC separation and characterization of its subunits. Journal of Chromatography A 917(1-2): 135- 145.

12. CLSI (2015) Performance Standards for Antimicrobial Disk and Dilution Susceptibility Tests for Bacteria Isolated from Animals. VET01S, ( $3^{\text {rd }}$ edn), Clinical and Laboratory Standards Institute, Wayne, Pennsylvania, USA.

13. Guedes AC, Barbosa CR, Amaro HM, Pereira CI, Malcata FX (2011) Microalgal and cyanobacterial cell extracts for use as natural antibacterial additives against food pathogens. International Journal of Food Science \& Technology 46: 862-870.

14. Pyörälä S, Taponen S (2009) Coagulase-negative staphylococci emerging mastitis pathogens. Veterinary Microbioly 134: 3-8.

15. Da Costa GM, Barros RA, Custódio DAC, Pereira, UP, Figueiredo DJ, et al. (2013) Antimicrobial resistance in Staphylococcus aureus isolated from mastitis in dairy herds from the state of Minas Gerais, Brazil. Arquivos do Instituto Biológico 80(3): 297-302.

16. Santos Neto TM, Mota RM, Silva LBG, Viana DA, Lima-Filho JL, et al. (2009) Susceptibility of Staphylococcus spp. isolated from milk of goats with mastitis to antibiotics and green propolis extracts. Letters in Drug Design \& Discovery 6(1): 63-68.

17. Bhateja P, Mathur T, Pandya M, Fatma T, Rattan A (2006) Activity of blue green microalgae extracts against in vitro generated Staphylococcus aureus with reduced susceptibility to vancomycin. Fitoterapia 77: 233235.

18. Shumin S, Dai W, Yu H, Wang Y, Wang X, et al. (2015) Antibacterial activity of aqueous and ethanolic extracts of Portulaca oleracea L. and 
Taraxacum mongolicum Hand-Mazz against pathogenic bacteria of cow mastitis. Indian Journal of Animal Research 49(6): 827-829.

19. Radhika D, Veerabahu C, Priya R (2012) Antibacterial activity of some selected seaweeds from the Gulf of Mannar Coast, South India. Asian Journal of Pharmaceutical and Clinical Research 5(4): 89-90.

20. Rajasulochana P, Dhamotharan R, Krishnamoorthy P, Murugesan S (2009) Antibacterial Activity of the Extracts of Marine Red and Brown Algae. Journal of American Science 5(3): 20-25.

21. Herrero M, Ibañez E, Cifuentes A, Reglero G, Santoyo S (2006) Dunaliella salina microalga pressurized liquid extracts as potential antimicrobials. Journal of Food Protection 69(10): 2471-2477.

22. El Shafaay SM, Ali SS, El-Sheekh MM (2016) Antimicrobial activity of some seaweed's species from Red sea, against multidrug resistant bacteria. The Egyptian Journal of Aquatic Research 42: 65-74.

23. Ghosh A, Das BK, Roy A, Mandal B, Chandra G (2008) Antibacterial activity of some medicinal plant extracts. Journal of Natural Medicines 62(2): 259-262.

24. Medina-Jaritz NB, Perez-Solis DR, Ruiloba de Leon FSL, Olvera-Ramírez R (2011) Antimicrobial activity of aqueous and methanolic extracts from Arthrospira maxima. In: Science against microbial pathogens: communicating current research and technological advances. Formatex Research Center pp. 1267-1271.

25. França CAI, Peixoto RM, Cavalcante MBI, Melo NF, Oliveira CJB, et al. (2012) Antimicrobial resistance of Staphylococcus spp. from smal ruminant mastitis in Brazil. Pesquisa Veterinária Brasileira 32(8): 747 753.

26. Philip K, Sinniah SK, Muniandy S (2009) Antimicrobial peptides in aqueous and ethanol extracts from microbial, plant and fermented sources. Biotechnol 8(2): 248-253.

27. El-Sheekh MM, El-Shafaay SM, Abo-Shad AM, El-Ballat E (2014) Antibacterial activities of different extracts of some fresh and marine algae. The Egyptian Society of Experimental Biology 10(1): 75-85.

28. Laport MS, Marinho PR, Santos OCS, Almeida P, Romanos MTV, et al. (2011) Antimicrobial activity of marine sponges against coagulasenegative staphylococci isolated from bovine mastitis. Veterinary Microbiology 155(2-4): 362-368.
29. Marinho PR, Muricy GRS, Silva MFL, De Marval MG, Laport MS (2010) Antibiotic-resistant bacteria inhibited by extracts and fractions from Brazilian marine sponges. Revista Brasileira de Farmacognosia 20(2): 267-275.

30. Santoyo S, Jaime L, Herrero M, Senorans FJ, Cifuentes A, et al. (2006) Functional characterization of pressurized liquid extracts of Spirulina platensis. European Food Research Technology 224(1): 75-81.

31. Ozdemir G, Karabay NU, Dalay MC, Pazarbasi B (2004) Antibacterial activity of volatile components and various extracts of Spirulina platensis. Phytotherapy Research 18(9): 754-757.

32. Priya S (2012) Analysis of value-added biochemical compounds and antimicrobial activity of green algae Chlorella vulgaris. Journal of Chemical and Pharmaceutical Research 4(5): 2577-2579.

33. Coppo E, Marchese A (2014) Antibacterial activity of polyphenols Current Pharmaceutical Biotechnology 15(4): 380-390.

34. Mendiola JA, Santoyo S, Cifuentes A, Reglero G, Ibáñez E, et al. (2008) Antimicrobial activity of sub-and supercritical $\mathrm{CO}_{2}$ extracts of the green alga Dunaliella salina. Journal of Food Protection 71(10): 2138-2143.

35. Srinivasakumar KP, Rajashekhar M (2009) In vitro studies on bactericidal activity and sensitivity pattern of isolated marine microalgae against selective human bacterial pathogens. Indian Journal of Science and Technology 2(8): 16-23.

36. Chaiklahanet R, Chirasuwan N, Triratana P, Loha V (2013) Polysaccharide extraction from Spirulina sp. and its antioxidant capacity. International Journal of Biological Macromolecules 58: 73-78.

37. Sekar S, Chandramohan M (2008) Phycobili Bermejo proteins as a commodity: trends in applied research, patents and commercialization. Journal of Applied Phycology 20(2): 113-136.

38. Sarada D, Kumar SC, Rengasamy R (2011) Purified C-phycocyanin from Spirulina platensis (Nordstedt) Geitler: a novel and potent agent against drug resistant bacteria. World Journal of Microbiology and Biotechnology 27(4): 779-783.

39. Najdenski HM, Gigova LG, Iliev II, Pilarski PS, Lukavsky J, et al. (2013) Antibacterial and antifungal activities of selected microalgae and Cyanobacteria. International Journal of Food Science \& Technology 48: 1533-1540. 